\title{
Characteristics of expert opinions on insanity accepted by NZ Courts
}

\author{
Graham W. Mellsop
}

\begin{abstract}
Background: Health and justice have to communicate whenever the question of legal responsibility is raised with respect to a person accused of a serious crime. Both recommendations and practices on expert report design and content vary widely.

Methods: This paper briefly reviews the characteristics of 27 reports accepted as persuasive in contested New Zealand cases.

Results and conclusions: Relative brevity, presenting the opinions within a court friendly structure, and emphasising the information available around the time of the events, as opposed to information clinically or legally reconstructed, all appear to be important.
\end{abstract}

Keywords: Legal insanity, Psychiatric expert opinion reports

\section{Background}

Health and justice have to communicate whenever the question of legal responsibility is formally raised with respect to a person accused of a serious crime. Clinical and legal definitions of insanity do not match up in a 1:1 fashion. Once a criminal charge has been laid, the New Zealand (NZ) Justice system operates on adversarial, as opposed to inquisitorial, principles. The defence can seek a verdict of not guilty by reason of insanity (NGRI). In which case, to assist the Court, both defence and prosecution seek independent psychiatric opinions on the applicability of criteria prescribed in section 23 of the NZ Crimes Act (1961) and subsequent, relevant, case law. From the outset the situation is contested in the sense that the prosecution and the defence seek opposite outcomes. Psychiatric evidence is presented to the court by expert witnesses whose opinions are separately sought by both the prosecution or the defence. Those witnesses are expected to be dispassionate and their opinions uninfluenced by who asked them or who arranges their payment. But only the expert(s) for one side apparently end up being believed.

The NGRI defence is usually only run where a guilty verdict would result in significant imprisonment. As in many jurisdictions the relevant law is similar to the

Correspondence: graham.mellsop@waikatodhb.health.nz

Department Psychological Medicine, University of Auckland, Auckland, New Zealand original British M'Naghten rules (Every-Palmer et al. 2014). It essentially requires that at the time of the act(s) the accused suffered from a "disease of the mind" of such a degree that either s/he did not know the "nature and quality of their actions" or if they did, they "did not know that their actions were wrong".

There is a small literature on forensic psychiatric report writing and a variety of alternate templates, schemata, and guidelines. Reputable textbooks generally refer to content issues and the need for impartiality, comprehensibility and demonstrated logic, but offer little guidance on structure (Galpin 2007; Bowden 1990; Freckelton 2007). Bowden (Bowden 1990) and Galpin (2007) refer to standard medical/psychiatric clinical headings and Freckleton (2007) only to principles. In NZ (population $4.5 \mathrm{~m}$; forensic psychiatrists, 45), Allnutt and Chaplow (2000) have argued that psychiatrists should resist giving opinions on the ultimate legal issue even when encouraged to do so by legal participants in the justice system. They also note that it is frequently necessary to obtain collateral information (such as family, development, health and other observations) from third parties and review other sources such as previous psychiatric notes, but they do not refer to using other witness statements or the police interview in the days immediately following the event, despite the Court's critical interest in the person's mental state at the time of the alleged offence.
Springer Open

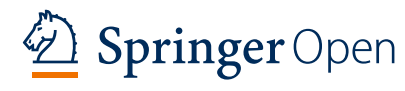

(c) The Author(s). 2016 Open Access This article is distributed under the terms of the Creative Commons Attribution 4.0 International License (http://creativecommons.org/licenses/by/4.0/), which permits unrestricted use, distribution, and reproduction in any medium, provided you give appropriate credit to the original author(s) and the source, provide a link to the Creative Commons license, and indicate if changes were made. 
Separating the "factual", which includes the inferred (Galpin), or the "findings" (Allnutt and Chaplow), from the opinion is typically recommended. The Courts decisions have been consistent with the authors opinions as an expert witness in 27 consecutive NZ cases. A brief, qualitative, examination of the characteristics of those reports may inform subsequent practice or textbook descriptions of report requirements in these very important situations.

This brief paper attempts to inform discussion on the characteristics of expert witness reports which are most helpful to the legal processes.

\section{Method}

In the last six years the present writer has prepared 27 reports at the request of either the defence or the prosecution in such contested cases. (Not included are three reports requested by the defence and where the writer opined that the accused was legally sane at the time of the acts as the issue was then never contested).

The 27 will be briefly reviewed in this paper to contribute to the guidance as to report characteristics which appear to influence court decisions.

\section{The results}

Most of the reports were prepared at the request of the Crown (prosecution), but the submitted reports favoured the defence in approximately half of the cases (See Tables 1 and 2). The table records diagnoses, such as schizophrenia [Sc], Bipolar disorder [B A D], the charges, such as murder or grievous bodily harm $[\mathrm{GBH}]$ and minimal prior treatment details such as AP [antipsychotic medication], LAI long acting injections].

Where the reports were at the request of the Crown (Prosecutor), but their conclusion favoured the defence argument for NGRI $(n=10)$, then in subsequent Court proceedings the psychiatric evidence was no longer contested. In two cases, once the defence had access to the Crown psychiatric conclusions rejecting the applicability of section 23 criteria, the insanity defences were withdrawn so those proceedings also became psychiatrically non-contested.

In each of the 27cases the Court's ultimate decision regarding NGRI was consistent with the writer's opinion. The following could be seen as characteristics of those 27 reports.

Table 1 Numbers of reports requested by the defence and prosecution and the numbers which the resultant reports favoured

\begin{tabular}{lll}
\hline Opinion & & \\
\hline & Sought by & Favoured \\
\hline Defence & 3 & 13 \\
Prosecution & 24 & 14 \\
\hline
\end{tabular}

1. Relative brevity: A median length of 8 (maximum 12) quarto sized pages compared with the median of 20 (maximum 60) for the contesting reports.

2. A greater emphasis on evidence available on the day of the event or in the preceding weeks, informing considerations of the presence or absence of psychiatric disorder. By contrast, the contesting reports generally placed greater emphasis on what defendants retrospectively said in the weeks or months following the alleged events - formal psychiatric interviews for these reports were typically performed 6-12 months after the event.

3. Reports usually did not adopt standard clinical record headings of, for example, history of illness, past history, family history, development, mental state, etc. Rather, they were usually structured around psychiatrically relevant observations under three time specified headings, viz. (i) Leading up to the day of the event; (ii) on the day; (iii) subsequently. The material summarised under those headings was extracted from the available witness statements, health records, Police and clinician interviews.

4. All 27 reports concluded with two sections, Psychiatric Opinion and Section 23 Opinion. Under the former heading the arguments for and against a disease of the mind and other Section 23 criteria were provided. Under the final, Section 23 heading, the writer always gave an opinion based most often on the balance of probabilities, though sometimes to the higher standard of beyond reasonable doubt. In practice, the latter only applied in relation to the presence or absence of the 'disease of the mind' component.

\section{Discussion and conclusions}

Twenty seven cases is a small sample for most quantitative research so this work needs to be considered qualitative, except for the fact that all the judicial decisions were consistent with the concluding opinions expressed in the writer's reports. The work was completed in small country, but it is clear that the New Zealand NGRI concept is very similar to that in the jurisdictions of many other countries (Every-Palmer et al. 2014; Mellsop et al. 2016). Those publications examine the many similarities and practical differences in how psychotic accused persons can utilise a legal insanity defence in many major countries of the Pacific Rim.

Psychiatrists have traditionally placed credence on information obtained from their own interviews. Although in theory they recognise the temporal instability of evidence, particularly where an interviewee has had endless "recall" sessions with relatives, legal counsel, and/or their treating team. Particularly in the forensic 
Table 2 Summary characteristics of the 27 reports

\begin{tabular}{|c|c|c|c|c|c|c|}
\hline Age/Sex & Request origin & Crime & Diagnosis & Ethnicity & Report Opinion & Prior Treatment Issues \\
\hline M 44 & Defence & $\mathrm{GBH}$ & Sc & Pacific & Insane & medication non-adherence \\
\hline M 23 & Crown & Murder & depr & European & Insane & Treatment non-adherent \\
\hline M 20 & Crown & Murder & Sc & Indian & Insane & IIIness not recognised by Psych \\
\hline M 30 & Crown & Arson & Drugs & Indian & Sane & Illicit drugs \\
\hline M 21 & Crown & Rape & B A D & European & Insane & Inadequate medication dose \\
\hline M 61 & Crown & $\mathrm{GBH}$ & Sc & Maori & Sane & No treatment \\
\hline M 40 & Crown & Murder & B A D & European & Insane & Low lithium prescribed \\
\hline M 40 & Crown & Murder & Sc & Asian & Insane & Had ceased LAI (depot) \\
\hline M28 & Crown & arson & B A D & Pacific & Sane & Severity not recognised by Psych \\
\hline M 36 & Defence & $\mathrm{GBH}$ & Sc & European & Insane & Illness not recognised \\
\hline M 30 & Crown & GBH & Sc & Indian & Sane & Illness not recognised \\
\hline 28 & Defence & Sexual assault & Drugs & African & Sane & No illness recognised \\
\hline M55 & Crown & Murder & Depression & European & Sane & Severity of illness not recognised \\
\hline M 38 & Crown & Sexual assault & Drugs & Asian & Sane & Drug use hidden \\
\hline M17 & Crown & Arson & Sc & Maori & Insane & Nil \\
\hline F24 & Crown & Murder & Drugs & Maori & Sane & Drug abuse \\
\hline M25 & Crown & Murder & Sc & European & Insane & Treatment resistant \\
\hline M40 & Crown & Murder & Drugs & Maori & Sane & No treatment \\
\hline$F 22$ & Crown & Attempted Murder & Sc & Maori & Sane & Under treatment \\
\hline F60 & Crown & Murder & Depr & Asian & Sane & Discontinued medication \\
\hline M32 & Crown & $\mathrm{GBH}$ & Sc & Maori & Insane & Illness unrecognised \\
\hline M31 & Crown & GBH & Sc & Indian & Sane & Dr ceased AP \\
\hline M26 & Crown & Murder & ?ASD & Asian & Sane & Nil \\
\hline M35 & Crown & Murder & Sc & Pacifica & Sane & Non adherence \\
\hline F39 & Crown & Murder & Sc & Indian & Insane & Psychosis unrecognised \\
\hline M23 & Crown & Murder & Sc & Pacifica & Insane & Overt psychosis not treated \\
\hline M 22 & Crown & $\mathrm{GBH}$ & Sc & Maori & Insane & Untreated \\
\hline
\end{tabular}

Footnotes: Sc schizophrenia, ASD Asperger's

field there is a necessity to be watchful for contamination by the rarer malingering, false memories or straightforward dishonesty. The emphasis in the 27 reviewed reports on the greater value of antecedent information, and that obtained on the actual day or subsequent police interview, may have appealed to a more cynical legal or judicial logic. To study this by having an open and independent examination of a series of reports from both prosecution and defence expert witnesses would possibly provide more reliable information, but the practicality of such a project is at best daunting.

Even the writer's relative brevity results in longer reports than one UK recommendation of 2-3 pages (Faulk 1988).

In contrast to the Allnutt and Chaplow view (Allnutt \& Chaplow 2000), it can be inferred that NZ Courts have no problem receiving clear psychiatric opinions on
Section 23 criteria, and do not regard this as preempting their own powers.

\section{Competing interests}

The author declares that he has no competing interests.

\section{Ethics approval and consent to participate}

The NZ legislation does not require formal ethical approval for non-interventional studies. No individuals have been identified in this report and in addition, as all these cases went to trial, the information in the reports is legally in the public domain, not subject to privacy laws.

Received: 1 September 2016 Accepted: 29 November 2016

Published online: 08 December 2016

\section{References}

Allnutt, S., \& Chaplow, D. (2000). General principles of forensic report writing. Australia and New Zealand Journal of Psychiatry, 34, 980-987.

Bowden, P. (1990). In E. R. Bluglass \& P. Bowden (Eds.), Principles and Practice of Forensic Psychiatry. UK: Churchill Livingstone.

Every-Palmer, S., Brink, J., Chern, T. P., Choi, W. K., Hern-Yee, J. G., Green, B., Heffernan, E., Johnson, S. B., Kachaeva, M., Shiina, A., Walker, D., Wu, K., Wang, 
X., \& Mellsop, G. W. (2014). Review of Psychiatric Services to Mentally

Disordered Offenders Around the Pacific Rim. Asia-Pacific Psychiatry, 6, 1-17. Faulk, M. (1988). Basic Forensic Psychiatry. Oxford: Blackwell.

Freckelton, I. (2007). In E. W. Brookbanks \& A. S. Simpson (Eds.), Psychiatry and the Law. Wellington: LexisNexis.

Galpin, G. (2007). In E. W. Brookbanks \& A. S. Simpson (Eds.), Psychiatry and the Law. Wellington: LexisNexis.

Mellsop, G., Choi, W. K., Every-Palmer, S., Green, B., Heffernan, E., Kachaeva, M., \& Shiina, A. (2016). Drug driven psychoses and Legal Responsibility or Insanity in Six Western Pacific Nations. International Journal of Law \& Psychiatry., $47,68-73$.

\section{Submit your manuscript to a SpringerOpen ${ }^{\circ}$ journal and benefit from:}

- Convenient online submission

- Rigorous peer review

- Immediate publication on acceptance

- Open access: articles freely available online

- High visibility within the field

- Retaining the copyright to your article

Submit your next manuscript at $>$ springeropen.com 